\title{
APPLICATION OF 2-D TRAVEL-TIME INVERSION OF SEISMIC REFRACTION DATA TO THE MID-CONTINENT RIFT BENEATH LAKE SUPERIOR
}

\author{
William J. Lutter \\ U.S. Geological Survey, Menlo Park, CA \\ Anne M. Trehu \\ Oregon State University, Corvallis, OR \\ Robert L. Nowack \\ Purdue University, W. Lafayette, IN
}

\begin{abstract}
The inversion technique of Nowack and Lutter (1988a) and Lutter et al. (1990) has been applied to first arrival seismic refraction data collected along Line $\mathrm{A}$ of the 1986 Lake Superior GLIMPCE experiment, permitting comparison of the inversion image with an independently derived forward model (Trehu et al., 1991; Shay and Trehu, in press). For this study, the inversion method was expanded to allow variable grid spacing for the bicubic spline parameterization of velocity. The variable grid spacing improved model delineation and data fit by permitting model parameters to be clustered at features of interest. Over 800 first-arrival travel-times were fit with a final RMS error of $0.045 \mathrm{~s}$. The inversion model images a low velocity central graben and smaller flanking halfgrabens of the Midcontinent Rift, and higher velocity regions $(+0.5$ to $+0.75 \mathrm{~km} / \mathrm{s})$ associated with the Isle Royale and Keweenaw faults, which bound the central graben. Although the forward modeling interpretation gives finer details associated with the near surface expression of the two faults because of the inclusion of secondary reflections and refractions that were not included in the inversion, the inversion model reproduces the primary features of the forward model.
\end{abstract}

\section{INTRODUCTION}

The Midcontinent Geophysical Anomaly (MGA) extending from Kansas to Lake Superior, is one of the most distinctive features on North American gravity and magnetic maps. Interpretation of the MGA as a Proterozoic rift dates back to the mid-fifties (Black, 1955; Lyons, 1959).

Deep seismic reflection profiles recorded in 1986 by the Great Lakes International Multidisciplinary Program on Crustal Evolution (GLIMPCE) in conjunction with the U.S. Geological Survey and the Geological Survey of Canada imaged shallow and deep crustal structure associated with the Midcontinent Rift System. Five seismic reflection profiles were recorded across the Midcontinent Rift in Lake Superior (Behrendt et al., 1988). These reflection profiles reveal a very deep asymmetrical central graben (Cannon et al., 1989). During this experiment, seismometers (solid circles in Figure 1) were deployed onshore as well as on Copyright 1993 by the American Geophysical Union

Paper Number 93GL00171

0094-8534/93/93GL-00171\$03.00 the lake bottom to record large-aperture wide-angle reflected and refracted information from the 128-liter tuned airgun array. A model for the wide-aperture seismic refraction profiles recorded along Line $\mathbf{A}$, based on forward modeling of seismic and gravity data has been discussed by Trehu et al. (1991).

The purpose of this paper is to discuss inversion of GLIMPCE Line A travel-times using the technique of Nowack and Lutter (1988a) and Lutter et al. (1990) to provide an image of the velocity structure based solely upon first-arrival information that can be compared to the forward model (Shay and Trehu, in press). The application of inversion methods to delineate earth structure allows the rapid determination of crustal models while also providing statistical measures of model resolution and error. By imaging the smallest structural details that are statistically

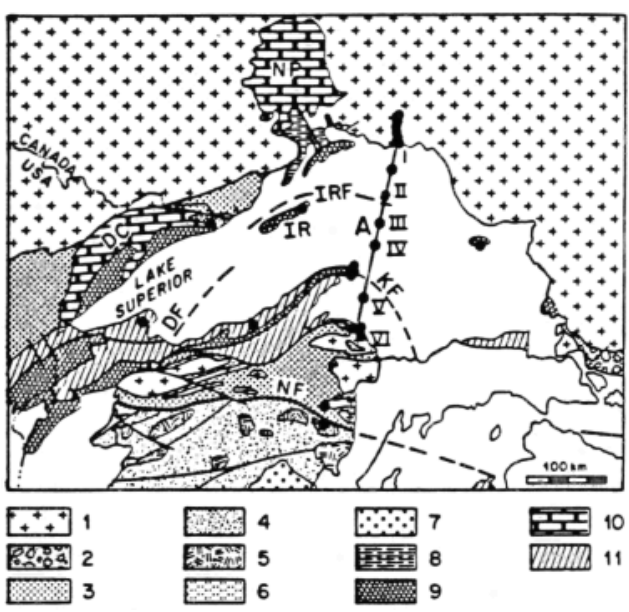

Fig. 1. Location map of 1986 GLIMPCE seismic reflection profiles in Lake Superior overlain on a simplified geological map (after Trehu et al., 1991). The thick solid line shows seismic reflection line $A$. Dashed lines the Douglas fault-DF, Duluth complex-DC, Isle Royale fault zone-IRF, Keweenaw fault-KF, and Niagara fault-NF. The geologic units shown are: 1-Superior Province; 2-Huron Supergroup; 3-Marquette Range Supergroup; 4-Penokean calc-alkaline volcanics; 5-Penokean plutons; 6-Baraboo quartzite; 7-Granite-rhyolite; 8-MRS lower sediments; 9MRS mafic volcanics; 10-MRS mafic intrusions; 11-MRS upper sediments. Solid dots show the 12 recording stations used to collect refraction/wide angle reflection data during shooting of profile A. Stations referred to in the text are indicated by Roman numerals. 
resolvable, an inversion-derived velocity model can help discriminate between alternative seismic interpretations.

\section{INVERSION METHOD}

Recent two-dimensional refraction tomography methods allow model parameterizations with a variety of grid cell shapes and interpolation schemes (White, 1989; Zhu and McMechan, 1989; Zelt and Smith, 1992). The technique used to invert first-arrival travel-times in this study incorporates a splined velocity parameterization and a rapid procedure for the calculation of the partial derivatives (Nowack and Lutter, 1988a; Lutter et al., 1990). The parameterization of the velocity model and the ray tracing algorithm are based on SEIS83 (Červeny et al., 1977; Cervený and Pšencik, 1984). Model velocities, specified at nodes in the bicubic spline parameterization, allow both lateral and vertical gradients within layers.

In the initial inversion step, rays are traced through a starting model employing a sparse number of model parameters. A linearized system of equations relating travel-time residuals, $\delta \mathrm{T}$, and model changes, $\delta \mathrm{V}$, can be inverted for corrections to the model that improve the data fit. The introduction of damping can be used to stabilize the inversion. The damped least squares solution can be written

$$
m_{g}=\left(A^{T} A+\varepsilon^{2} I\right)^{-1} A^{T} d
$$

where $A$ is the partial derivative matrix, $d$ the data residual vector, $\varepsilon$ the damping parameter, and $\mathrm{m}_{\mathrm{g}}$ is the model correction vector.

The Paige-Saunders conjugate-gradient algorithm (Paige and Saunders, 1982) is used to solve the damped least squares system in (1) and compares favorably with other methods of solving large tomographic systems (Nolet, 1985). The iteration of the linearized inversion is continued with an increasing number of model parameters until a stopping criterion based on an F-test is met (Menke, 1984). The density of node positions is increased to image finer spatial detail in the model and to lower the data residual vector. However, only the fewest number of model parameters needed to explain the data are used.

Model resolution and standard deviation of model parameters are calculated as described by Nowack and Lutter (1988b) and Lutter et al. (1990). The linearized resolution matrix acts as a filter on the true earth model parameters resulting in the estimated model $m_{g}=R m_{\text {true }}$. Diagonal elements of the resolution matrix range between values of zero and one. Non-zero diagonal elements indicate the degree of averaging or the linear dependence of the true model parameters as represented by the inverted model. Consequently, model parameters associated with diagonal elements of the resolution matrix greater than 0.5 are considered meaningful for this study.

The model parameterization was expanded for this study to allow variable horizontal and vertical grid spacing. In this way, grid points (nodes) may be concentrated near the surface. This approach improves modeling of higher near-surface velocity gradients while maintaining adequate numbers of nodes for modeling lower magnitude velocity gradients at depth. The use of a variable grid can reduce RMS error and lead to improved delineation of model detail in regions of higher node density at a small cost in associated model resolution values (Lutter, 1990).

\section{Inversion of First-Arrival Travel-Times}

A 128-liter tuned airgun array fired every two minutes provided a source spacing of approximately $333 \mathrm{~m}$ along Line A. First-arrivals are clearly discernible to distances greater than $90 \mathrm{~km}$ from the receiver. The first-arrival travel-times from gathers at receivers I-VII were digitized (Shay, 1990) and then resampled at $0.75-\mathrm{km}$ intervals for offsets $<70-\mathrm{km}$ and at $2.0-\mathrm{km}$ intervals for offsets $>70 \mathrm{~km}$ using a one-dimensional spline for interpolation.

A series of inversions were performed in which the number of model parameters (nodes) increased to improve the spatial delineation of model detail and to minimize starting model bias. A laterally homogeneous model with velocities ranging between 5.0 to $7.5 \mathrm{~km} / \mathrm{s}$ at depths between 0 to $30 \mathrm{~km}$ provided a starting model independent of the forward model. A series of inversions with an increasing number of model parameters culminated in a 250-node model which imaged the greatest spatial detail.

The result of inverting a 250-node grid of velocity parameters with variable node spacing in distance and depth is shown in Figure 2A. Black dots located along the

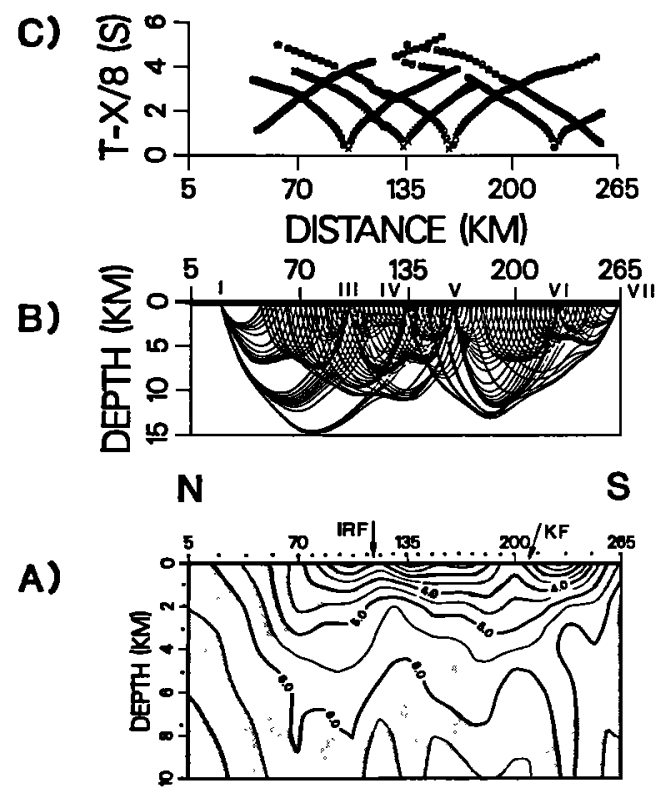

Fig. 2. A) Contour diagram of isovelocity lines for the final 250 node inversion model with a contour interval of $0.5 \mathrm{~km} / \mathrm{s}$. Black dots along the vertical depth axis and horizontal distance axis indicate the positions of rows and columns of velocity nodes for the model. Between 70 and $200 \mathrm{~km}$, nodes are positioned at intervals of $8.125 \mathrm{~km}$, while on the flanks nodes are at $16.25 \mathrm{~km}$ intervals. Vertically, node intervals increase with depth with nodes positioned at $0,1,2,3,5,7.5,10,15,25$, and $40 \mathrm{~km}$. Shaded regions of the model show resolution values less than 0.5 and are poorly resolved by the 250 node inversion. The Isle Royale fault zone (IRF) and Keweenaw fault $(\mathrm{KF})$ are labelled. Vertical exaggeration is 13:1. B) Ray-paths associated with the 250 node inversion model. The horizontal position of receivers are denoted as I-VII. C) The fit between the observed travel-times, solid dots, and computed travel-times, $x$ 's, for the final model. 
depth and distance axis indicate the horizontal and vertical positions of nodes in the final velocity model. Velocity nodes are clustered horizontally between 70 and $200 \mathrm{~km}$ to improve the spatial delineation of shallow crustal velocity structure. The fine grid and greater complexity of the model resulted in a maximum ray-penetration depth of 15 km (Figure 2B).

The fit to travel-times for the final velocity model are shown in Figure 2C. Over 800 rays were traced through the final model; the RMS error of the model with respect to the data was $0.045 \mathrm{~s}$. The damping value used for the inversion was $0.25 \mathrm{~s}^{2} / \mathrm{km}$, which constrained velocity estimates at node positions to within $0.1 \mathrm{~km} / \mathrm{s}$ while preserving resolution values $>0.5$ throughout much of the model.

Resolution of the 250-node model is generally good (ie. diagonal elements of the resolution matrix greater than 0.5 ) for depths less than $8 \mathrm{~km}$, as indicated by the unshaded region of Figure 2A. Comparison with the ray diagram in Figure 2B indicates that model details shallower than 1.5 to $3 \mathrm{~km}$ with diagonal resolution values greater than 0.5 are associated with the locations of the receiver positions for this source-receiver geometry. These resolution values suggest that for the source-receiver geometry of Line A, positioning receivers adjacent to shallow crustal regions of interest would improve the resolution of these features.

Significant shallow crustal features imaged by the 250node inversion include three low velocity basins associated with the central graben of the Midcontinent Rift System (Cannon et al., 1990; Trehu et al., 1991). The central basin is associated with the central half-graben of the Midcontinent Rift System and is bounded by a 30-km wide zone of higher velocities corresponding to the Isle Royale fault zone (at approximately $115 \mathrm{~km}$ in Figure 2A) and by a smaller velocity increase corresponding to the Keweenaw fault to the south (at approximately $210 \mathrm{~km}$ ). The basin associated with the northern half-graben is positioned between the Slate Islands at a horizontal profile distance of $70 \mathrm{~km}$ and the Isle Royale fault zone. A smaller basin occurs just to the south of the Keweenaw fault between Manitou Island and the southern shore of Lake Superior $(265 \mathrm{~km})$.

\section{Comparison to the Forward MOdel}

The same set of first-arrival travel-times used for the inversion in this study, augmented by secondary arrivals, were used in forward modeling by Shay and Trehu (in press). This permits a direct comparison between an inversion derived model and one based on forward modeling (Figure 3). The forward model was also parameterized by using bicubic splines, but included velocity discontinuities.

More detail is apparent in the forward model for several reasons. First, the forward model incorporates the two-way travel-time to reflection horizons interpreted from Cannon et al. (1989) as constraints on "layer" boundaries. Second, earlier shallow seismic refraction results provided additional constraints for the forward model as described in Shay and Trehu (in press). Third, secondary reflected and refracted arrivals are not included in the inversion model but are included in the forward model. Nevertheless, the inversion has imaged the salient details (similar velocities,

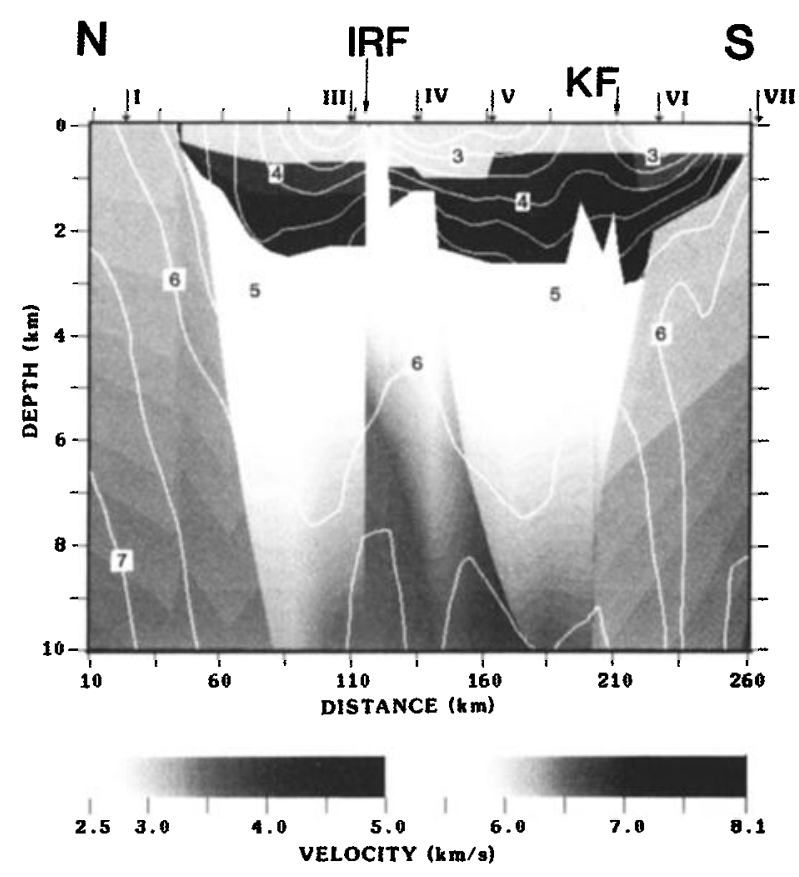

Fig. 3. Direct comparison of the inversion results of this study with the forward model of Trehu et al. (1991). Shading represents velocities from the forward model. The Isle Royale fault zone (IRF) and Keweenaw fault (KF) are labelled. Isovelocity contours represent velocities from the 250 node inversion model displayed in Figure 2A. Vertical exaggeration is $20: 1$.

depths and widths) for velocity anomalies associated with the central graben, flanking half-grabens and faults. Although the formal resolution of individual features in the model cannot be calculated, synthetic seismograms qualitatively provide additional constraints on forward model features and are discussed by Shay and Trehu (in press).

Well resolved portions of the 250-node model (unshaded region of Figure $2 \mathrm{~A}$ ) image a velocity uplift of approximately +0.5 to $+0.75 \mathrm{~km} / \mathrm{s}$ associated with the Isle Royale fault zone. This feature, imaged to a depth of at least $10 \mathrm{~km}$, is a low-angle feature dipping to the south at approximately 15 degrees. The velocity uplift broadens from approximately $25 \mathrm{~km}$ at the surface to over $100 \mathrm{~km}$ at 10-km depth. A high velocity gradient to a depth of $3 \mathrm{~km}$ grades into a lower-magnitude velocity gradient at depth.

A two-pronged pattern of velocity discontinuities associated with the Isle Royale fault zone (upper $\mathrm{km}$ near $115 \mathrm{~km}$ in Figure 3) and Keweenaw fault (2-km depth near $210 \mathrm{~km}$ ) within the forward model occur in regions of low resolution in the inversion model. While increasing the node density might improve the imaging of fault detail, the region (unshaded) of diagonal resolutions greater than 0.5 would further decrease. It must be concluded that these features are spatially averaged in the first-arrival inversion.

The inversion image supports the geologic and tectonic interpretation of the forward model. In summary, the highvelocity gradient imaged to a depth of $3 \mathrm{~km}$ corresponds to an Upper Keweenawan post-volcanic sedimentary sequence that fills a broad post-rift basin (Cannon et al., 1989). Lower-magnitude velocity gradients at depth image syn-rift volcanic and sedimentary rocks which fill a northern and central half-graben. Velocity uplifts adjacent to the Isle 
Royale fault zone and Keweenaw fault bound the central half-graben to a depth of $3-5 \mathrm{~km}$ and result from post-rift compression on reactivated rift-bounding normal faults.

ACKNOWLEDGMENTS This research has been supported by NSF Grants EAR-8904169 (W.J.L., R.L.N.), EAR-9018217 (R.L.N.) and EAR-8904413 (A.M.T.). Purdue University also partially supported W.J. Lutter in the form of a David Ross Fellowship. Acknowledgement is also given to the donors of the Petroleum Research Fund for partial support of this research (AMT).

\section{REFERENCES}

Behrendt, J.C., A.G. Green, W.F. Cannon, D.R. Hutchinson, M.W. Lee, B. Milkereit, W.F. Agena, and C. Spencer, Crustal structure of the Midcontinent rift system: results from GLIMPCE deep seismic reflection profiles, Geology, 16, 81-85, 1988.

Black, W.A., Study of the marked positive gravity anomaly in the northern Midcontinent region of the United States, Geol. Soc. Am. Bull., 66, 1531, 1955.

Cannon, W.F., A.G. Green, D.R. Hutchinson, M. Lee, B. Milkereit, J.C. Behrendt, H.C. Halls, J.C. Green, A.B. Dickas, G.B. Morey, R. Sutcliffe and C. Spencer, The North American Midcontinent rift beneath Lake Superior from GLIMPCE seismic reflection profiling, Tectonics, 8, 305-332, 1989.

Cervený, V., I.A. Molotkov, and I. P̌sencik, Ray Method in Seismology, Universita Karlova, Praha, Czechoslovakia, 1977.

Cervený, V. and I. P̌senčik, SEIS83 - numerical modeling of seismic wave fields in 2-D laterally varying layered structures by the ray method, in Documentation of Earthquake algorithms (ed. E.R. Engdahl), REPORT SE-15, World Data Center (A) for Solid Earth Geophysics, Boulder, Colorado, 36-40, 1984.

Lutter, W.J., Travel-time and amplitude inversion applied to the 1986 PASSCAL Ouachita experiment and the 1986 GLIMPCE Lake Superior experiment, Ph.D. Thesis, 375 pp. Purdue University, W. Lafayette, IN 1990.

Lutter, W.J., R.L. Nowack and L.W. Braile, Seismic imaging of upper crustal structure using travel times from the PASSCAL Ouachita experiment, J. Geophys. Res., 95, 4621-4631, 1990.

Lyons, P.L., The Greenleaf anomaly, a significant gravity feature, in Symposium on the Geophysics of Kansas,
Kan. St. Geol. Surv. Bull., 137, (ed. W.M. Hambleton), 105-120, 1959.

Menke, W., Geophysical Data Analysis: Discrete Inverse Theory, Academic Press, 1984.

Nolet, G., Solving or resolving inadequate and noisy tomographic systems, J. Comp. Phys., 61, 463-482, 1985.

Nowack, R.L. and W.J. Lutter, Linearized rays, amplitude and inversion, Pure and Appl. Geophys, 128, 401-421, 1988a.

Nowack, R.L. and W.J. Lutter, A note on the calculation of covariance and resolution, Geophys. J., 95, 205-207, $1988 \mathrm{~b}$.

Paige, C.C. and M.A. Saunders, LSQR: an algorithm for sparse linear equations and sparse least squares, $A C M$ Trans. on Math. Soft., 8, 43-71, 1982.

Shay, J.T., Structure of the crust beneath Lake Superior from forward modeling of large aperture seismic data, M.S. Thesis, 119 pp., Oregon State University, Corvallis, OR, 1990.

Shay, J.T., and A. Trehu, Crustal structure of the Midcontinent Rift beneath Lake Superior, J. Geophys. Res., in press, 1993.

Trehu, A., P. Morel-a-Huissier, R. Meyer, Z. Hajnal, J. Karl, R. Mereh, J. Sexton, J. Shay, W.K. Chan, D. Epili, T. Jefferson, X.R. Shih, S. Wendling, B. Milkereit, A. Green, and D. Hutchinson, Imaging the Midcontinent Rift Beneath Lake Superior Using Large-Aperture Seismic Data, Geophys. Res. Lett., 18, 625-628, 1991.

White, D.J., Two-dimensional seismic refraction tomography, Geophys. J., 97, 223-245, 1989.

Zelt, C.A., and R.B. Smith, Seismic traveltime inversion for 2-D crustal velocity structure, Geophys. J. Int., 108, $16-34,1992$.

Zhu, X., and G.A. McMechan, 2-D Tomographic Imaging of Velocities in the Wichita Uplift-Anadarko Basin Region of Southwestern Oklahoma, 79, 873-887, 1989.

W.J. Lutter, U.S. Geol Surv, 345 Middlefield Road, MS 977, Menlo Park, CA 94025

R.L. Nowack, Dept. of Earth and Atmos. Sci., Purdue University, W. Lafayette, IN 47907

A.M. Trehu, Oceanography, Oregon State Univ, Ocean Admin Bldg 104, Corvallis, OR 97331-5503

(Received October 7, 1992;

revised December 7, 1992;

accepted January 12, 1993) 